IRSH 59 (20I4), Special Issue, pp. 89-I I 2 doi:I0.I0I7/So0208590I4000I70 (C) 2014 Internationaal Instituut voor Sociale Geschiedenis

\title{
Empire on their Backs: Coolies in the Eastern Borderlands of the British Raj*
}

\author{
L I P O K M A R D Z Ü V I C H Ü \\ North East India Studies Programme, Jawaharlal Nebru University \\ New Delhi I I0067, India \\ E-mail: postlipok@gmail.com
}

\begin{abstract}
AвSTRACT: In the nineteenth century, colonial officials relied heavily on coercion to recruit "coolie" labour for "public works" and to provide various support services in the North-East Frontier of British India. "Treaties" with defeated chiefs and the subsequent population enumeration and taxation were strongly oriented to the mobilization of labour for road building and porterage. Forced labour provided the colonial officials with a steady supply of coolies to work on the roads as well as carriers for military expeditions. In mobilizing labour resources, however, colonial officials had to create and draw upon native agents such as the headmen and interpreters who came to play a crucial role in the colonial order of things. Focusing on the Naga Hills, this article will examine the efforts of the colonial state to secure a large circulating labour force, the forms of labour relations that emerged from the need to build colonial infrastructure and the demand for coolies in military expeditions, the response of the hill people to labour conscription and its impact on the hill "tribes".
\end{abstract}

Besides his dao the Naga carried a spear, iron-spiked at both ends. On his back, he carried his personal property in a commodious conical basket. On the top of that came the sixty-pound load, which he was carrying for the Maharani. ${ }^{{ }}$

Powell Millington, I9I 2

The colonial labour regime on the Assam tea plantations has been an important field of study for historians researching the eastern borderlands of British India. Focusing on the complex relationship between questions of labour, capital, and colonial policy, these studies have drawn our attention to the various forms of recruitment, the modes of exploitation, and changing

* I would like to thank Radhika Singha for her critical advice and valuable comments on earlier drafts of this article, as well as Joy L.K. Pachuau and Manjeet Baruah for reading and commenting on an earlier draft.

I. Powell Millington, On the Track of the Abor (London, I912), p. 22. 
labour relations on the tea plantations. ${ }^{2}$ This body of research has broadened our conceptual understanding of colonial labour on the plantations and the interactions between planters, recruiters, labourers, and colonial government at varying levels. In contrast to these significant studies on the labour regime on the Assam plantations, the story of large numbers of circulating hill "coolies" in the eastern borderlands of the British Raj has remained strikingly neglected. Furthermore, the manpower resources generated through colonial "public works" on the frontier are often seen as "normal", self-evident effects of colonial rule and so are not discussed in historical works.

Focusing on the Naga Hills, ${ }^{3}$ this article examines colonial efforts to secure a large circulating workforce which could provide a steady supply of porters and labourers for road building. Colonial infrastructure improvements demanded heavy and continuous labour. In fact, studies on colonial "public works" in Orissa by Ravi Ahuja have shown how the construction of infrastructural road projects relied on "the widespread utilisation of forced and unpaid labour". They in turn instituted new forms of labour regime. ${ }^{4}$ As Ian Kerr shows in the context of railway construction, colonial infrastructural projects could also stimulate the flow of labour between different regions even as opportunities for wage labour multiplied and labour markets expanded.' In another significant work, Shekhar Pathak draws our attention to pre-colonial labour practices in the Kumaun hills and how the colonial state mobilized labour resources by appropriating the existing system of begar or unpaid forced labour in British Kumaun. ${ }^{6}$ In the Kumaun hills, as Pathak points out, the

2. Some important works on colonial labour systems in British Assam are Jayeeta Sharma, “'Lazy' Natives, Coolie Labour, and the Assam Tea Industry”, Modern Asian Studies, 43 (2009), pp. I 287-I 324; Rana P. Behal, "Coolie Drivers or Benevolent Paternalists? British Tea Planters in Assam and the Indenture Labour System”, Modern Asian Studies, 44 (2010), pp. 29-51; idem, "Power Structure, Discipline and Labour in Assam Tea Plantations Under Colonial Rule", International Review of Social History, 5 I (2006), pp. I43-172; idem and Prabhu P. Mohapatra, “'Tea and Money versus Human Life': The Rise and Fall of the Indenture System in the Assam Tea Plantations 1840-1908”, Journal of Peasant Studies, 19:3-4 (1992), pp. $142-172$.

3. In the nineteenth century, as the British expanded into the North-East Frontier, certain groups of people were classified under the generic category "Naga" such as Ao, Angami, Chang, Lotha, Sema, Konyak etc. These categories are products of colonial encounter and therefore problematic. The various Naga groups who inhabited the geographical space named after them, i.e. the "Naga Hills", are the focus of this paper. For an important work on the processes of knowledge production on the "Nagas" see Andrew West, "Writing the Nagas: A British Officer's Ethnographic Tradition", History and Anthropology, 8:I-4 (1994), pp. 55-88.

4. Ravi Ahuja, Pathways of Empire: Circulation, "Public Works" and Social Space in Colonial Orissa (c.1780-1914) (Hyderabad, 2009), p. 290.

5. Ian J. Kerr, Engines of Change: The Railroads that Made India (London, 2007), p. 39.

6. Following the occupation of the hill district of Kumaun, the British continued the existing begar system, which originated under its earlier rulers, and subjected the hill population to forced unpaid labour. See Shekhar Pathak, "The Begar Abolition Movements in British 
British not only "regularized" the system of begar but also intensified its "oppressive effects", leading to popular mass movements against the system. ${ }^{7}$ This analysis of the system of begar reveals how subject populations in the hill district of Kumaun were constantly ensnared in the web of colonial labour requirements. The present article resonates with this literature by analysing the mechanisms through which colonial officials mobilized labour resources in the hills, and how the local population in the Naga Hills came to be subordinated as "coolies" in the imperial enterprise of road building.

In the nineteenth century north-east, an expanding frontier in the hill tracts generated a demand for a flexible and mobile labour corps. Annual tours by frontier political officials meant that coolies had to be found to carry their baggage and supplies. A steady supply of labour was also needed to develop colonial infrastructures such as roads in the hills. While roads enabled the British to extend their reach into the hills, they also enhanced the ability of the colonial state to extract labour resources from the hill communities. If, in the words of James Scott, the hills constituted ungoverned spaces of refuge, ${ }^{8}$ this did not necessarily imply that the state was incapable of extracting resources such as labour from the hills. In fact, the notion of scattered areas and communities provided the colonial state with a legitimating factor in converting the local population into pliable labouring subjects. In the process, colonial officials relied heavily on coercion to recruit "coolie" labour for "public works" and to provide various support services in the region. "Treaties" with defeated chiefs and the subsequent population enumeration and taxation were strongly oriented to the mobilization of labour for road building and porterage. This was a process of labour impressment, intimately related to the expansion of the wage-labour market, which would turn the "primitive tribes" into "coolies". Moving across colonial boundaries these coolies sustained the supply lines of the imperial army, and built infrastructures such as roads and military outposts.

Colonial officials could not, though, simply mobilize the huge manpower from the hills by imposing it from above. They had to engage with

Kumaun", Indian Economic and Social History Review, 28 (199I), pp. 26I-279; for a discussion of the link between the begar system, the expansion of the reserved forests, and the demand to abolish this "feudal" system by the nationalist leaders in the Kumaun hills, see Richard P. Tucker, A Forest History of India (Delhi, 2012), pp. 99-103.

7. Ibid.

8. James C. Scott, The Art of Not Being Governed: An Anarchist History of Upland Southeast Asia (Hyderabad, 2010). However, given the importance of settled agriculture, especially among the Angami Nagas, the idea that hill societies and their practices were constantly engaged in the act of escaping the state may perhaps not be applicable in all cases. In fact, one factor that attracted the British to the Angami hills was the existence of a settled agrarian system, and it was from this agrarian-based society that the British sought to mobilize resources to meet their imperial needs in the hills. 
the "traditional" structures and institutions. In their effort to tap into the labour resources, the colonial state had to create and draw upon native agents such as headmen and interpreters. However, coolie work was much resented by the Nagas, who countered it by developing tactics to avoid work or, at least, to minimize their labour. This article will study the mechanisms employed by the colonial state in the recruitment of labour, the reactions of hill peoples to labour demands, and the changing role of the hill "tribes" in the imperial enterprise.

\section{“EXCELLENT MEN FOR MOUNTAIN WORK”}

In I873, Alexander Mackenzie, Junior Secretary in the Government of India, in his letter to the Secretary of the Foreign Department, remarked that "the want of carriage", especially for hill works, was "the great[est] difficulty" confronted by British officials in the North-East Frontier. ${ }^{9}$ In fact, requisitioning labour was a constant colonial anxiety since concern for crops and families often compelled local labourers engaged in road works to return to their homes and villages when needed. For instance, in I873, an official working on the Golaghat-Samaguting road reported: "Beginning of December and end of February [...] work on the roads came to a standstill as coolies left to their homes to cut and store their rice crops." ${ }^{\circ}$

As an alternative to the labour requirements in the Naga Hills, colonial officials often drew upon the Nepali coolies who had been brought in to work in the Assam tea gardens. These Nepali coolies, mostly recruited from Darjeeling and Jalpaiguri, were primarily employed in working on the hill roads and as porters in the episodic military campaigns against the "wild hill tribes". The diversion of coolies from the tea plantations, however, resulted in vehement opposition from the tea planters as it created "a considerable scarcity of this labour" seriously impeding "the prospect of many gardens". "I "Sudden call for their services", wrote Mackenzie, "places the planters in an unfair position and leads to much grumbling". Moreover, requisitioning these coolies suddenly and marching them "hurriedly to field service" resulted in sickness and much loss of life. ${ }^{\mathrm{I2}}$

To meet the labour exigencies, in I 873 Alexander Mackenzie proposed to form a permanent labour corps for the North-East Frontier. Such a labour corps was essential, Mackenzie argued, since campaigns on the North-East Frontier "depend[ed] more on the efficiency of the coolies than of the soldiers". And besides, "We have yet very much to do in

9. National Archives of India, Foreign and Political Department, New Delhi [hereafter, F\&PD] -

A, October 1873 , nos 277-293A.

го. F\&PD - A, September 1873, nos 219-229.

I I. F\&PD - A, October I873, nos 277-293A.

I 2. Ibid. 


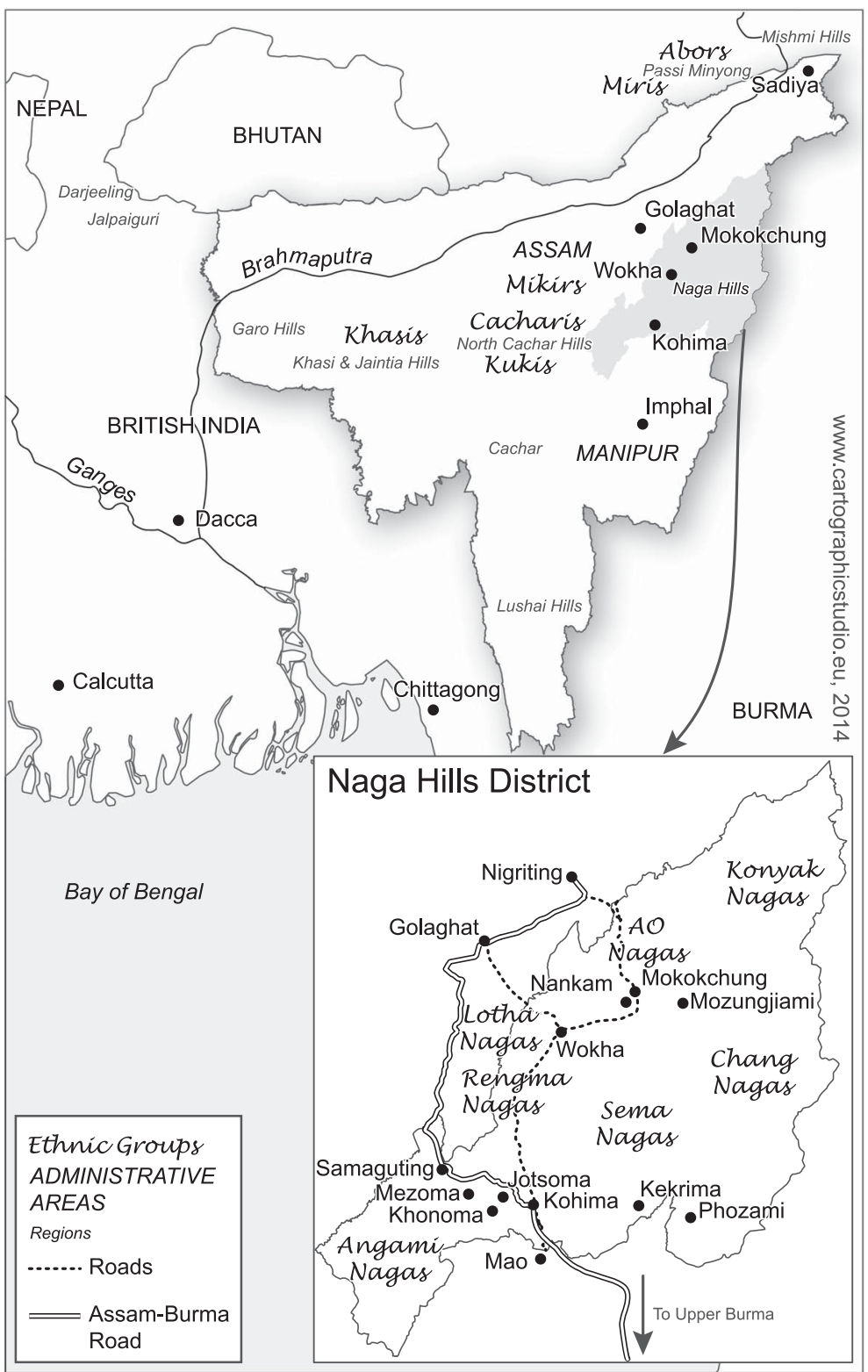

Figure I. Map of Assam during the early twentieth century. 
opening out our hill tracts by proper roads." ${ }^{13}$ Mackenzie hoped to enlist the Nepali coolies, whom he considered to be "excellent men for mountain work". ${ }^{14} \mathrm{He}$ argued that there was more than enough work in "opening hill roads" to justify a permanent workforce. Mackenzie knew that such a labour corps would be indispensable to the government as the empire expanded on the North-East Frontier: "In the Garo and Naga Hills, and on the south frontier of Cachar, there is work enough to occupy such a corps for years to come." ${ }^{\text {Is }}$

However, in the scheme of colonialism, policies were also often framed upon contingent circumstances. With the introduction of the Inner Line Regulation in I 873, mobility between the "hills" and the "plains" was placed under stricter restrictions and movement of people became more regulated. ${ }^{16}$ In this respect, having a more organized coolie corps became essential. A large labour force could now move across the hills only under the supervision of colonial officials. Thus, in I 876 under the supervision of the Political Agent of the Naga Hills, Nepali coolies recruited from Darjeeling reportedly carried out most of the hill work on the Wokha road. ${ }^{17}$ In I879, another group of I 50 Nepali coolies from the Garo Hills, along with 50 Mikir coolies, were employed on the Samaguting-Kohima road by Guybon Henry Damant, the Deputy Commissioner of Naga Hills. ${ }^{18}$

Even as "imported" coolies were being increasingly employed in the Naga Hills, contradictory elements seep into the official narratives. Colonial officials or "men-on-the-spot" soon expressed their reservations about the practicability of engaging the "plainsmen" in the hills. Expressing his discomfort about the Punjabi coolies, John Butler, the Political Agent of the Naga Hills, remarked in I875: "I do not consider the Punjabi plainsmen, as a rule, make the best coolies for hill work." ${ }^{9}$ On the contrary, he found hill people like the Khasis and the Kukis "cheerful and jolly". In his evaluation, their work was "such a marked contrast to the sad and weary manner of the Punjabi that it was a matter of general remark". ${ }^{20}$ In another striking instance, in I876, Jack Francis Needham, the Assistant Political Agent in the Naga Hills, ridiculed the plains Assamese coolies and the Gurkha coolies (enlisted mostly from Darjeeling and Jalpaiguri), who were employed on the Golaghat-Wokha road.

\footnotetext{
I3. Ibid.

I4. Ibid.

I s. Ibid.

I6. The Inner Line Regulation was introduced in I873 and restricted all British subjects, including the people in the hills, from crossing the inner line without a pass or permit.

I7. F\&PD - B, March i 876 , nos I63-167.

I 8. F\&PD - A, January i 880 , nos $495-497$.

I9. F\&PD - A, December I875, nos 9I-99.

20. Ibid.
} 
Dismissing them as "useless for road making", he preferred to replace them with 100-200 Cacharis. ${ }^{21}$

Such apprehensions about the "plainsmen's" competence for hill works provided grounds for colonial authorities like Colonel James Johnstone, the Officiating Political Agent of Naga Hills, to advocate strongly the tapping of "local" labour from within the hills. Writing in I 878 Johnstone declared that:

Government should not have been burdened with a heavy expense annually for coolies from the plains, when local labours was at hand, nor should the disgraceful spectacle have been seen of coolies forced up from the plains to work on the Hills Roads, because we were afraid to make the lazy hillmen perform their share of necessary work. ${ }^{22}$

Arguing against the government policy of importing coolies, Colonel Johnstone thus pressed for more aggressive measures to obtain labour from within the hills. Such a policy was deemed crucial both for political and financial reasons. Extraction of labour from the Naga Hills was to be a more forceful process. At a particular juncture, the Anglo-Naga war of I 879-I 880 provided a crucial context for this enterprise.

\section{REBELLION AND PACIFICATION}

In October I 879 G.H. Damant, the Deputy Commissioner of Naga Hills, had called on the Angami villages of Khonoma, Mezoma, and Jotsoma to comply with the government's revenue demand and to supply coolie labour. ${ }^{23}$ The Angamis were targeted because they were the most outspoken opponents of forced labour. Besides, Damant remarked, these Angami villages were used to levying contributions on their weaker neighbours. Thus, once large villages such as Khonoma and Jotsoma were compelled to pay revenue, weaker villages would "follow their lead". ${ }^{24}$ The Angamis, however, refused to comply with the colonial demand. To push forward the colonial policy, Damant proceeded to Khonoma with a detachment of fifty-four sepoys. As the military column advanced into Khonoma, the entire force was wiped out and the Angamis laid siege to the military base in Kohima. ${ }^{25}$ It took almost a year and a massive

21. F\&PD - A, September I 876, nos I42-145.

22. F\&PD - A, October 1878 , nos $7-51$.

23. F\&PD - A, March i 880 , nos $33 \mathrm{I}-395 \mathrm{D}$.

24. In 1879 , G.H. Damant, the DC of Naga Hills, wrote to the Chief Commissioner of Assam stating that, "the larger villages in the Angami community have been for generations past in the habit of levying contributions from all their weaker neighbours whether of their own or different tribes, and they will not readily pay revenue in place of receiving it". See F\&PD - A, January I 880 , nos 498-5i I.

25. F\&PD - A, March I880, nos 33 I-395D. 
mobilization of resources to suppress what has been described as "the last Angami rebellion". ${ }^{26}$

A treaty imposed after pacification included an obligation to provide labour, and an annual house tax of Rs 2. In what would become a familiar argument, the imposition of state corvée was justified on the grounds that it was the only way of "making the Nagas pay something for their administration". ${ }^{27}$ In addition, the figures of the headman or lambardar and the interpreter or dobhashi were introduced to simplify, facilitate, and systematize revenue and labour demands.

Under the new politico-economic regime, the Nagas were required to work for Is days a year at a rate of 4 annas a day. To distribute the burden of building a particular road, colonial officials also developed the idea of rotating corvée labour from different villages. ${ }^{28}$ However, in calculating the labour resources, the agricultural cycle of the hill people also had to be taken into account to ensure that enough stocks of food, particularly rice, were available locally. Thus, in I 882, Charles Alfred Elliott, the Chief Commissioner of Assam, directed the district officials to draw upon the "contributed labour" only when the Nagas were not engaged in agricultural work:" "Among the Lhotas, part of March was occupied in sowing and from May to November, in working and reaping the crop; the month [sic] from December to February and April are those in which labour may safely be demanded." ${ }^{\circ}$ Such a caution against disturbing the "traditional" pattern of cultivation was also because "we want them to cultivate enough rice for themselves and for us too": ${ }^{\text {I }}$

When the regular roster of Naga labour is made out, there will be no difficulty in calling on the men whose time it is to work to come in, and until that time much can be done to prevent hardship to individuals by distributing the corvee as widely as possible..$^{32}$

26. A force of $\mathrm{I}, \mathrm{I} 35$ of all ranks along with two mountain guns (from Calcutta) was mobilized under the command of General Nation, from Shillong. This was in addition to Colonel James Johnstone's force of 2,000 Manipur troops, including his own personal escort of 30 men as well as a frontier force of 50 men; F\&PD - A, February I 880 , nos 275-289. The transport train organized during the expedition, for transport and supply, comprised 700 boats, 200 carts, 305 elephants, 227 ponies, and 405 coolies. See V.J. Moharir, "Operations on the Eastern Frontier", in B.N. Majumdar (ed.), History of the Army Service Corps, II: $1858-1913$ (New Delhi, 1984), p. 306.

27. F\&PD - A, February i 880 , nos 29I-305.

28. National Archives of India, Home and Political Department [hereafter, H\&PD] Judicial, March i 882, nos 58-67.

29. F\&PD - A, June I 882 , nos I $34-137$.

30. Ibid.

31. F\&PD - A, August I882, nos 70-77.

32. F\&PD - A, January I 882 , nos I 34-I37. In working out the labour contribution, Elliott argued that ensuring a steady supply of labour was only possible by expanding corvée labour in the hills. In other words, corvée labour would continue to be indispensable for the colonial state to maintain a continuous supply of labour in the hills. 
Since the rhythm of agricultural cycle and the demand for labour often clashed with the need for continuous labour on the road, it was through such strategies that the British hoped to secure a steady supply of labour as well as a crucial supply of rice for themselves in the hills.

\section{RATIONALIZING LABOUR IMPRESSMENT}

The efforts of the colonial officials to get the Nagas to turn up to labour on "public works" or for portering requirements were not, however, readily or easily complied with. ${ }^{33}$ The kind of force which had to be used to extract labour continuously for public works and frontier portering is illustrated in Major Thomas Bernard Michell's acknowledgement that if he needed coolies, "to go a day or two's journey from Kohima, almost the only means I have of getting them is to send a party of police to the village from which they are requisitioned, seize the headmen, and confine them in the quarter-guard at Kohima until the coolies are forthcoming". ${ }^{34}$ In effect, the system of forced labour was then considered by colonial authorities as "a necessary step towards linking these savages into the first rudiments of civilized life". ${ }^{35}$

In the logic of colonialism, coercion was justified since, as Major William Ewbank Chambers categorically remarked, "no rate of pay will induce any man to work as coolly and the only means was by impressments of labour". ${ }^{36}$ Impressing labour also became more forceful especially in a context in which the creation of a district capital at Kohima in I88I pushed the government to structure grand plans of "public works" to consolidate its rule in the newly established territory. The Naga Hills Administration Report for the year I882-I883 thus recorded 20,000 coolies as employed "voluntarily" on the local roads in the headquarter subdivision Kohima. Another 30,000 coolies were reportedly engaged in roadworks and the carriage of rice in the Wokha subdivision. ${ }^{37}$

In an environment where opposition to labour impressment began to circulate in the Assam plains, the need for and legitimacy of forced labour

33. "Some months ago", Major T.B. Michell wrote, in May i 88 I, "I sent constables with orders to the headmen of Jampi and other villages in its neighbourhood to furnish their quota of labour. The order was not obeyed and we have not received a single coolie from any of those villages." Faced with such hostility, Michell sought to send out a strong detachment of troops so as "to enforce obedience"; Proceedings of the Chief Commissioner of Assam, Foreign Department, July i882, Assam State Archive, Guwahati [hereafter, PCCOA, FD, ASA].

34. Ibid.

35. F\&PD - A, February I 880 , nos 29I-305.

36. F\&PD - A, August I880, no. I75.

37. Report on the Administration of the Province of Assam for the Year I882-I883 (Shillong, I 884 ). 
had to be constantly reiterated and demonstrated. ${ }^{38}$ For instance, Robert Cunliffe Low, Commandant on the Eastern Frontier, stated that: "No impressment of any description is being resorted [...] in procuring labour. If labour is required, a requisition is made to the civil authorities with whom it rests to obtain voluntary labour or in difficulty to impress the labour required." ${ }^{39}$ The argument here was that "voluntary" labour was "traditional" and therefore could continue to be treated as a resource at the disposal of district officials. Moreover, impressment, in the language of colonial authorities, operated only to sustain the continuity of the "civilizing" work in which they were engaged, which occasioned the need to maintain a stable labour force.

Impressments were, as is to be expected, much resented by the local inhabitants, who would often adopt drastic strategies to evade the oppressive colonial labour regime. In one instance, a certain Captain Williamson starkly expressed his uneasiness to the Chief Commissioner of Assam: "The demand for Naga labour naturally falls on those villages near [...] Kohima [and] unless relief is afforded, it may result in the people abandoning their homes and dispersing among distant villages in the East which would place us in an awkward predicament." ${ }^{\circ}$ Williamson's cautious note to the Chief Commissioner came at a time when a "heavy and disproportionate degree" of forced labour coupled with "unsystematic and spasmodic" methods had reportedly put pressure on a large number of inhabitants to leave Samaguting to avoid these exactions. ${ }^{4 I}$

To bring the "disproportionate" labour demands under "some system and order", colonial authorities subsequently initiated a systematization of local labour in the Naga Hills. ${ }^{42}$ This involved measures such as setting up a register. In I88 I Charles A. Elliott, the Chief Commissioner of Assam, thus proposed to maintain "a register [...] showing the number of adult males in each village, whether near or far". Explaining the usefulness of such a register Elliott wrote:

Whenever labour is required, this register should be consulted and the Lambardar should be ordered to send in so many men for so many days work to such a place.

38. What seemed to be occurring was that British orders stipulating the supply of labour for the repair of roads, etc. often glossed over and therefore blurred the social class/caste distinctions in the Assam plains, much to the displeasure of the social elite. To meet their objections, in I 882 the Assam administration under Charles A. Elliott, Chief Commissioner of Assam, initiated a series of consultations with the various district officials in the plains during which details of the existing operation of labour impressments was discussed. The general conclusion was that impressment of labour could not be done away with, but that ways had to be found to keep it within more acceptable limits and to allocate the burden more systematically and equitably; H\&PD Judicial, March I882, nos 58-67.

39. F\&PD Secret - E, May I 885 , nos I 39-I 78 .

40. F\&PD - A, August I 880 , nos 70-77.

4I. F\&PD - A, April I 880, nos 264-26; F\&PD - A, January I 882, kept with nos I34-I 37 . 42. "Memorandum on the Administration of the Naga Hills District", in PCCOA, FD, May I88I. 
When the next demand is made, the villages, which supplied the first indent, should be excused, and application should be made to the next in order; and in this way the whole of the villages on the register should be laid under contribution before a second demand is made on the first village. ${ }^{43}$

While instructing the district officials to ensure early implementation of this "important reform", Charles James Lyall, Officiating Secretary to the Chief Commissioner, expressed the hope "that when he [Chief Commissioner] visits the hills next spring he may find such a roster in force at least in Kohima and the villages adjoining it and the route down to the plains". ${ }^{44}$ By creating a more organized and finely tuned system of labour conscription, colonial authorities thus saw in the register a means to solve the great need for labour in the hills.

The aim of the register was to distribute the demand for labour more equitably between the households and villages, and hence simplify and systematize tax and labour conscription lists in the Naga Hills. Yet, this mechanism clearly did not end the prevailing system of forcible recruitment of supposedly voluntary labour. ${ }^{45}$ In fact, it was not intended to bring an end to such a system but, as we shall see later, only to take the responsibility for forcible recruitment from the shoulders of British officers and transfer it to those of the chiefs and headmen.

\section{THE POLITICS OF HOUSE TAX}

Closely linked with the labour conscription was the gradual evolution of a rationalized and standardized tax assessment in the Naga Hills. In I 882, the house tax was fixed at the rate of Rs 2 for the Angamis and Rs I for the Rengmas and the Lothas. ${ }^{46}$ The argument was that the Angamis practised terrace cultivation and engaged in trade, and so were "much richer" than those "who practise[d] the system of cultivation called jbumming". ${ }^{47}$ Taxation thus placed each household under the direct control of a centralized authority for the first time. ${ }^{48}$ Paying revenue was also cast as a "rite of passage": "A savage who pays revenue considers himself a

\footnotetext{
43. Ibid.

44. PCCOA, FD, July i 882.

45. Well into the early half of the twentieth century, incidents of impressment in the Naga Hills are found in colonial records. For instance, the tour diary of H.C. Barnes, the DC of Naga Hills, for I9I6 includes this entry: "the Sibsagar local boards have not yet made the road from Santok Hat to Naginimara passable for carts. So I 35 coolies had to be impressed from a distance and sent to Nazira”; “Tour Diary of H.C. Barnes, D.C., Naga Hills, I916”, Government Record Cell, Nagaland Secretariat, Kohima [hereafter, GRC].

46. F\&PD - A, January I 882 , nos I $34-\mathrm{I} 37$.

47. PCCOA, FD, July i 882.

48. Julian Jacobs, The Nagas: Hill Peoples of Northeast India: Society, Culture and the Colonial Encounter (London, I990), p. 23.
} 
British subject bound to carry out all orders given him, while a savage who does not pay revenue considers himself independent and free to obey orders or not as [he] chooses." 49

The imposition of a house tax in the Naga Hills also fell in with the imperial project of introducing the "primitive tribes" to the disciplining power of wage labour capitalism. While taxes were gradually increased, those persons unable to raise money through the sale of their agricultural or pastoral surpluses were often forced into the labour market in search of wages. In fact, large numbers of Nagas were pushed into "public works" in the region by the need to pay the house tax..$^{\circ}$ That this was the desired effect is also evident from cases in which road-building projects were cited as a reason for enhancing the house tax on nearby villages. Thus in I 900 the Commissioner of Assam ordered an increase in the house tax in the Angami hills from Rs 2 to Rs 3, arguing that wages earned by working on the Assam-Burma road had privileged the Angami "tribe" who lived along this route. ${ }^{5 \mathrm{I}}$ From the Naga perspective, the imposition of taxation was a turning point in their history. ${ }^{52}$ A Sangtam Naga villager in the early twentieth century complained that "when we were administered we had to sell our buffaloes to pay the tax". ${ }^{33}$ While some Nagas worked as coolies on colonial "public works" sites, there were others who were often driven to work as transport carriers for the colonial officials in addition to providing various support services at the frontier, as we shall see below.

\section{CARRYING LOADS}

The period after the Anglo-Naga War of i $879-1880$ was followed up by the practice of long regular tours in the interior areas. These tours often resulted in episodic punitive expeditions against recalcitrant villages. In I 882 Charles A. Elliott, the new Chief Commissioner of Assam, decided that the District Commissioner (DC) should spend a full one-third of the

49. F\&PD, March I 880, nos 33 I-395D; see also Piketo Sema, British Policy and Administration in Nagaland, I88I-I 947 (New Delhi, I992), pp. I I 5-I 25.

50. Jacobs, The Nagas: Hill Peoples of Northeast India, pp. 38-40. Also see J.P. Mills, "Notes on the Effect on Some Primitive Tribes of Assam of Contacts with Civilization", in Census of India, 193 I (Delhi, I933), I, pt IIIB, p. I47.

5I. An estimated Rs I 8, I 5,643 lakhs was reportedly spent in the Naga Hills section of this Assam-Burma route. In I895, a large number of Naga labour gangs had been employed on this road project. "This tribe", the Commissioner of Assam thus remarked, "has gained more than any other tribe by the money, which has recently been spent in these hills on public works of considerable magnitude, more especially in the villages in close proximity to the main lie of road". See F\&PD External - B, October I895, nos I52-I54, and, F\&PD External - A, December 1900, nos. 24-26.

52. Jacobs, The Nagas: Hill Peoples of Northeast India, p. 23.

53. Cited in ibid. 
year on district tours. ${ }^{54}$ Covering every village in his jurisdiction, the DC was instructed to "enquire into their revenue assessment [and] their supply of contributed labour". 55 To give one example of this practice, in I 88 I-I 882 the district tour undertaken by Thomas Bernard Michell, the Political Officer of Naga Hills, and Robert Blair McCabe, Deputy Commissioner of Naga Hills, took 102 days. ${ }^{56}$ On these tours, almost all transportation was on foot, in the absence of carts, boats, or "roads", and the Naga coolies emerged as an irreplaceable means of transport in the hills.

In conjunction with the tours, the British also set in motion a series of "military promenades" to consolidate their control over the people and territory in the interior hill areas. These "military promenades", as one British official explained, were "expeditions made by the Deputy Commissioner with an armed escort among the Frontier tribes". In December I 884, Robert B. McCabe, the Deputy Commissioner of Naga Hills, thus inaugurated one of the earliest "military promenades" to the eastern Angami villages along the Manipur border to the east of Kohima. ${ }^{57}$ Announcing the intent of the expedition, McCabe remarked:

[...] this is the first occasion on which a party has proceeded into these hills trusting to obtain carriage from village to village, and I considered that the success or failure of this attempt would enable me better than any other condition to gauge the real attitudes of these tribes towards our government. ${ }^{58}$

On 25 December, reaching the trans-frontier village of Razami, $\mathrm{McC}$ abe requisitioned thirty-five coolies from the headmen. However, early next morning, only twenty coolies turned up to transport the baggage and supplies of McCabe's column. To ensure that the village fully met the stipulated labour requirement, an exasperated McCabe took ten sepoys into the village and "demonstrated forcibly that orders were meant

54. One major function of this colonial regulation was the administrative division and organization of space. In 1905, the Imperial Gazetteer records show two subdivisions, Kohima and Mokokchung, in the Naga Hills district, along with a chain of territory being annexed into "the empire's geography”. For some early instances, Samaguting in I866, Wokha in 1878 , Kohima in I88I, the Ao Naga country in I889, the Semas and the Eastern Angamis (now Chakesang) in 1906, etc., see Imperial Gazetteer of India (Delhi, I905), XVIII, p. 287.

55. F\&PD - A, January I 882, nos I 34-I 37; F\&PD - A, January I 882, no. 35. Charles A. Elliott declared in his memoir of I 882 : "I attach the greatest importance to constant and free personal intercourse between district officers and their assistants on the one hand, and that this intercourse is best secured when the officers are as little at their headquarters and as much possible on tours in the district."

56. F\&PD - A, January i 882 , no. 35 .

57. According to McCabe, the proposed expedition would march through "Razami, Thecholumi, Khizobami, and Losemi, to Lozaphehomi where I could call in the Melomi men and return via Khromi and Purabami, to the Nummuh spur on the eastern frontier of the Naga Hills district"; PCCOA, FD, November I885.

58. Ibid. See also F\&PD External - A, May i 885 , nos 175-18 г. 
to be obeyed". This punitive action seemed to have had the desired effect, as McCabe remarked that "[i]n less than five minutes over 70 coolies turned out, and $[\ldots]$ we were enabled to make a very quick march to Thecholumi." "9 As a result of this intervention, McCabe claimed to have faced no difficulty in obtaining carriage throughout the whole expedition. In the ensuing years, with tours and expeditions becoming an important feature of the colonial administration, district officials would often resort to coercive measures to get men to transport supplies as well as to make roads in the hills.

Coolies accompanying the punitive expeditions were issued with meagre rations or none. Instead they were often made to live off the land or otherwise to forage for food in the villages deserted by the populace, who often fled when such expeditions approached. "No special supplies were taken for the coolies", noted Alexander Porteus, the Officiating DC of Naga Hills, in I889, during a punitive expedition against trans-Dikhu Naga villages. ${ }^{60}$ This, as Porteous explains, was because "in a deserted village ample supplies of pigs and rice are usually forthcoming" ${ }^{6 \mathrm{I}}$ At other times, where travelling required covering longer distances with fewer habitations, additional coolies were added to accompany each detachment to carry a few days' supply of food and $z u$ (local fermented liquor) for the marching column. They also supplemented the men who fell sick or were wounded. These measures, as Porteous claims, were based on "experiences in these short expeditions". ${ }^{62}$

In the Naga Hills, coolies accompanying troops were sometimes also required to travel on long journeys over distant areas. This was rather unpopular as it not only took the coolies away from their homes and fields for extended periods, ${ }^{63}$ but also often placed them in danger as the expeditions involved passing through hostile areas. "Their [the Ao coolies from Nunkum] alarm at hearing that they were to be taken into the Sema country was so great that, not withstanding they were under guard, almost the whole number succeeded in escaping, without demanding their pay during the night", wrote Porteous in $1887 .{ }^{64}$ Desertion, however, could convey different meanings in different frontier contexts. It could mean a sense of the coolie's notion of a boundary. Crossing beyond a

59. Ibid.

60. F\&PD External - A, May i889, nos 209-2 г2.

6I. Ibid.

62. Ibid.

63. For instance, J.E. Webster, DC of Naga Hills, wrote how Naga coolies employed during the trans-Dikhu tour loathed being away from home for a long time, but, more importantly, disliked "most missing the sowing season - March, April". See "Report on the Trans-Dikhu Tour”, PCCOA, Political Department [hereafter, PD], Political - A, August I9r3.

64. F\&PD External - A, November I 887, nos 64-66. 
certain point could also mean putting oneself in danger by entering a rival's territory or unsafe area. ${ }^{65}$ In response to these actions, colonial officials developed counter-strategies. Coolies were forced to do double marches, especially from those villages that refused to provide coolie service. ${ }^{66}$ Fines were imposed on villages for any delay in furnishing coolies to the district officials. For instance, Albert E. Woods, the Officiating DC of Naga Hills, wrote in I 893 that "One khel of Nerhema delayed in giving coolies and I fined them Rs. I00."67 Unwillingness to carry on with their loads was further met with harsh treatment, as was the case with the Angamis employed in the Abor expedition of I9I I-I9I 2. ${ }^{68}$ It was through such penalizing measures that colonial officials sought to turn the supposedly "wild tribes" into a compliant labour force.

\section{CARRIER WORK IN FAR-FLUNG AREAS}

By the first decade of the twentieth century, Nagas began to be used as carriers in far-flung areas of the frontier. In fact, a series of tours and expeditions were planned in the Abor, Miri, and Mishmi areas by the British. An important purpose of these expeditions was to check on any possible Chinese influence in these areas. ${ }^{69}$ In January i9 I LieutenantColonel Philip Richard Thornhagh Gurdon, while arranging coolies for a

65. For instance, in his study on porterage in colonial Tanzania Stephen Rockel has shown how desertion among porters was often linked to the issue of security. See Stephen Rockel, "Wage Labor and the Culture of Porterage in Nineteenth Century Tanzania: The Central Caravan Routes", Comparative Studies of South Asia, Africa and the Middle East, I 5:2 (1995), pp. I 5-24. 66. "Tour Diary of K. Cantlie, officiating D.C., Naga Hills, I919”, GRC. Tours or expeditions in the hills were usually organized into stages. Depending on the location of the villages, a stage would normally mean covering a particular village by the marching column. The distance travelled by a tour party on a regular day (which normally involved covering one village or stage) could vary from 7 to 30 miles. In this sense "double marches" (which were usually carried out under compulsion) would mean making the coolies cover two stages or more in a day with their loads over steep and difficult country. In one instance, the Kekrima villagers were made to do a "double march" to Khezabama (Chizami) without halting at Tekhubama (Pfutsero) on the way.

67. "Tour Diary of Captain A.E. Woods, Officiating DC of the Naga Hills" for the month of April 1893, Sl. No. 434 (S), Kohima State Archive, Kohima [hereafter, KSA]. In another instance, finding that no coolies had arrived to carry their baggage, Keith Cantlie, the DC, fined the Khozama village a sum of Rs 50. See "Tour Diary of K. Cantlie, officiating D.C., Naga Hills, I919", GRC.

68. A. Bentinck, the Assistant Political Officer in the Abor expedition of I9II-I9I2 wrote: "We tried to make an early start, but [...] the coolies particularly the Angamis gave any amount of trouble and over an hour was lost in getting clear the camp [...] throughout the day they continued putting down their loads on every possible occasion." Nevertheless, "the correction administered to the principal offenders last evening had an excellent effect on the Nagas and we got off in good time"; F\&PD Secret - E, November 1912, nos 599-690.

69. For instance see "Report of Mr. N. Williamson, Assistant Political Officer, Sadiya and his tour in the Mishmi Hills", Government of East Bengal and Assam [hereafter, GEB\&A], PD, Political - A, September I9I0. 


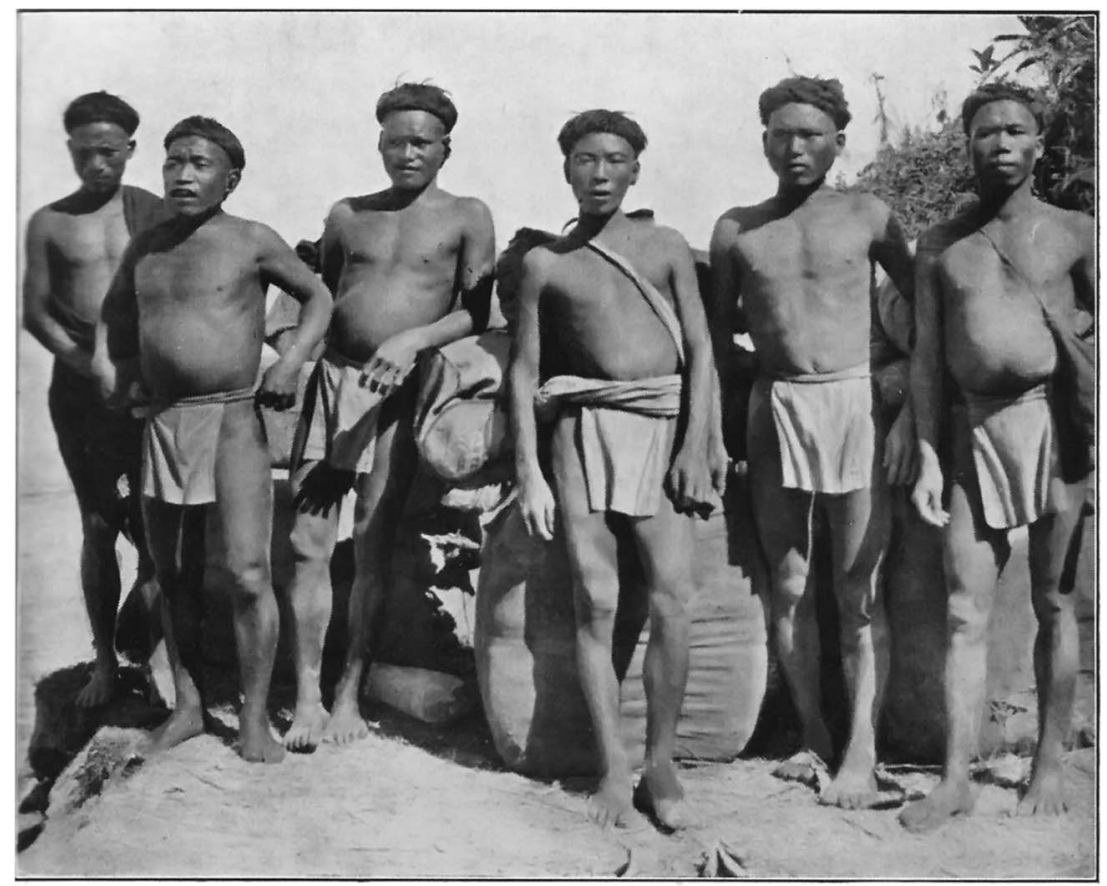

"THE UNSOPHISTICATED NAGA IS THE CHILd OF NATURE."

Figure 2. As the caption for this picture in the original source from I9I 2 makes clear, obtaining coolie labour was accompanied by a typically exoticizing and racist view of the Naga by the British.

Photograph: Angus Hamilton, from In Abor Jungles, Being an Account of the Abor Expedition, the Mishmi Mission and the Miri Mission (London, 19I2), p. I58.

tour of Abor country, preferred to employ 400 Ao, Lotha, and Sema Naga coolies since "these have been found the most useful for tours of this nature" ${ }^{\circ}$ In 1913, around 700 Semas and 100 Lothas were further employed by John Edward Webster, the DC of Naga Hills, for a trans-Dikhu tour. $^{71}$ Relying on Naga coolies placed frontier officials "in the enviable position of being independent of local transport". ${ }^{2}$ This was especially so as Naga coolies were considered more skilled and efficient when out in camp. During a tour of Passi Minyong country in March 1908, Noel Williamson, Assistant Political Officer at Sadiya, thus remarked, "Some of the Aos have

70. "Tour by the Assistant Political Officer, Sadiya, in the Abor country", GEB\&A, PD, Political - A, January i9i I.

7r. "Report on the Trans-Dikhu Tour", PCCOA, PD, Political - A, August I9I 3.

72. "Diary of a Tour of the Assistant Political Officer Sadiya", GEB\&A, PD, Political - A, March I 909 . 
been out in camp several times in the Naga hills [...] and are quite proficient in putting up a tent and helping generally." 73

Prior to embarking on an expedition, the stores and supplies for the military column were packed into loads of fifty or sixty pounds for the coolies. Angus Hamilton gives one such description during the Abor expedition in I9I r: "As all stores had to be portered by the Naga coolies through the jungle, careful packing was an important feature of the transport arrangements. Everything was put up, therefore, in loads of fifty or sixty pounds' weight." "74 It was these crucial assortments of supplies, transported by the coolies on their backs, which largely enabled the British officials and sepoys to travel to the interior areas and enforce their rule. ${ }^{75}$ For their labour service the Naga coolies were paid " 4 annas a day and free rations" for the duration of these expeditions. ${ }^{76}$ Apart from carrying provisions and military equipment, the Naga coolies also performed tasks such as building roads when not on the march. In I909, during a tour of the Mishmi Hills, Noel Williamson, the Assistant Political Officer at Sadiya, engaged fifty Lotha Nagas to construct a bridle path from the Tiju river to Sati in the Mishmi Hills, covering a distance of about ninety-two miles. ${ }^{77}$ Earlier, in February 1908, Williamson had employed thirty Ao Nagas from Nankam in clearing jungles and cutting roads in and round Sadiya. After completing their work at Sadiya, the Ao coolies were employed as transport carriers for a tour of the Abor villages. $^{78}$ By using these same coolies for various other tasks, colonial officials sought not only to ensure the presence of a steady workforce but also to keep costs low during the expeditions.

In the first few decades of the twentieth century, the colonial authorities began to distinguish certain communities in the Naga Hills as ideal for transport carriers. They were assessed and praised for their physical capacity to carry heavy loads. For instance, in 1923 John Henry Hutton, the DC of Naga Hills, wrote:

The physical powers of the Angami are considerable, for though he is not athletic in a gymnastic way, he has great powers of endurance, being able to do forced marches of thirty to forty miles on successive days over exceedingly steep

\section{Ibid.}

74. Hamilton, In Abor Jungles, p. I 30.

75. For instance, the rations carried by the coolies for the sepoys and followers during the Chinglong expedition included items such as, tea, salt, Dhal, rice, ghi, chillies, turmeric, ginger, garlic, gur, rum, as well as medical kits, etc. See "Chinglong Expedition", PCCOA, PD, Political - A, March I9I3.

76. "Report on the Trans-Dikhu Tour", PCCOA, PD, Political - A, August I9r 3.

77. "Report of Mr. N. Williamson, Assistant Political Officer, Sadiya and his Tour in the Mishmi Hills", GEB\&A, PD, Political - A, September I910.

78. "Diary of a Tour of Mr. N. Williamson, Assistant Political Officer, Sadiya", GEB\&A, PD, Political - A, March i 909 . 
country. He can stand exposure well $[\ldots]$ and is also able to carry very considerable burdens, the standard load being $60 \mathrm{lb}$. The women can also carry loads, but with less endurance. ${ }^{79}$

Such descriptions of the endurance and physical capacity of the Naga coolies, however, tended to conceal the harsh and unpleasant conditions under which coolies operated; besides, coolies accompanying military columns were often caught in skirmishes resulting in injury or death. ${ }^{80}$

\section{COOLIE WORK AND LOCAL RESPONSE}

While some Nagas turned out to work as transport coolies, there were others who began to seek out wage labour in the hills. This was often linked to the payment of house tax or the opportunity to earn money for their own personal wants. Drawn into wage labour by corvée and the house tax, subsequently Nagas also began to ask for and bargain over wages. In fact, the early twentieth century witnessed the different communities competing in an emergent labour market, especially in and around the district headquarters, Kohima. For instance, in November I9I7 John Henry Hutton, the DC of Naga Hills, was confronted by a group of labourers from Kekrima demanding a rise in the coolie rate from the then current 6 annas. In pressing their case, the labourers argued that since other neighbouring villages were being paid 8 annas by the government, they should therefore be allowed the same equivalent rate. ${ }^{8 \mathrm{r}}$ This incident reveals how, with their gradual integration into a wagelabour market, Nagas were now aware of the prevailing wage rates and could draw on this knowledge to bargain over wages with the district officials while making available their labour services.

The growing availability of labour in the wage market also meant that contractors involved in state projects could choose to keep wages low and turn to those labourers willing to work at a lower wage. In doing so, other Naga villages that relied on colonial public works sites to earn cash could find themselves in a difficult position, with no work to fund their tax payments. For instance, in June 1938, the gaonburha (Assamese village leader) of Khabvuma village complained to Eric Thomas Drummond Lambert, the DC of Naga Hills, that "they cannot get any money to pay house tax" because "the contractor will not employ them". This was despite them living "close to the [road] slip". Instead, much to the annoyance of

79. J.H. Hutton, The Angami Nagas (London, I92I), p. 20. See also, Frontier and Overseas Expeditions from India (Calcutta, I9I I), VII, p. I33.

80. For instance, during the Chinglong expedition in 1913 the casualties among the coolie corps included nine killed, five badly wounded, and twenty with slight wounds. See "Chinglong Expedition", Assam Secretariat Proceedings, PD, Political - A, March I9I3.

81. "Tour Diary of J.H. Hutton, D.C. of Naga Hills, for the Month of November 1917", GRC. 


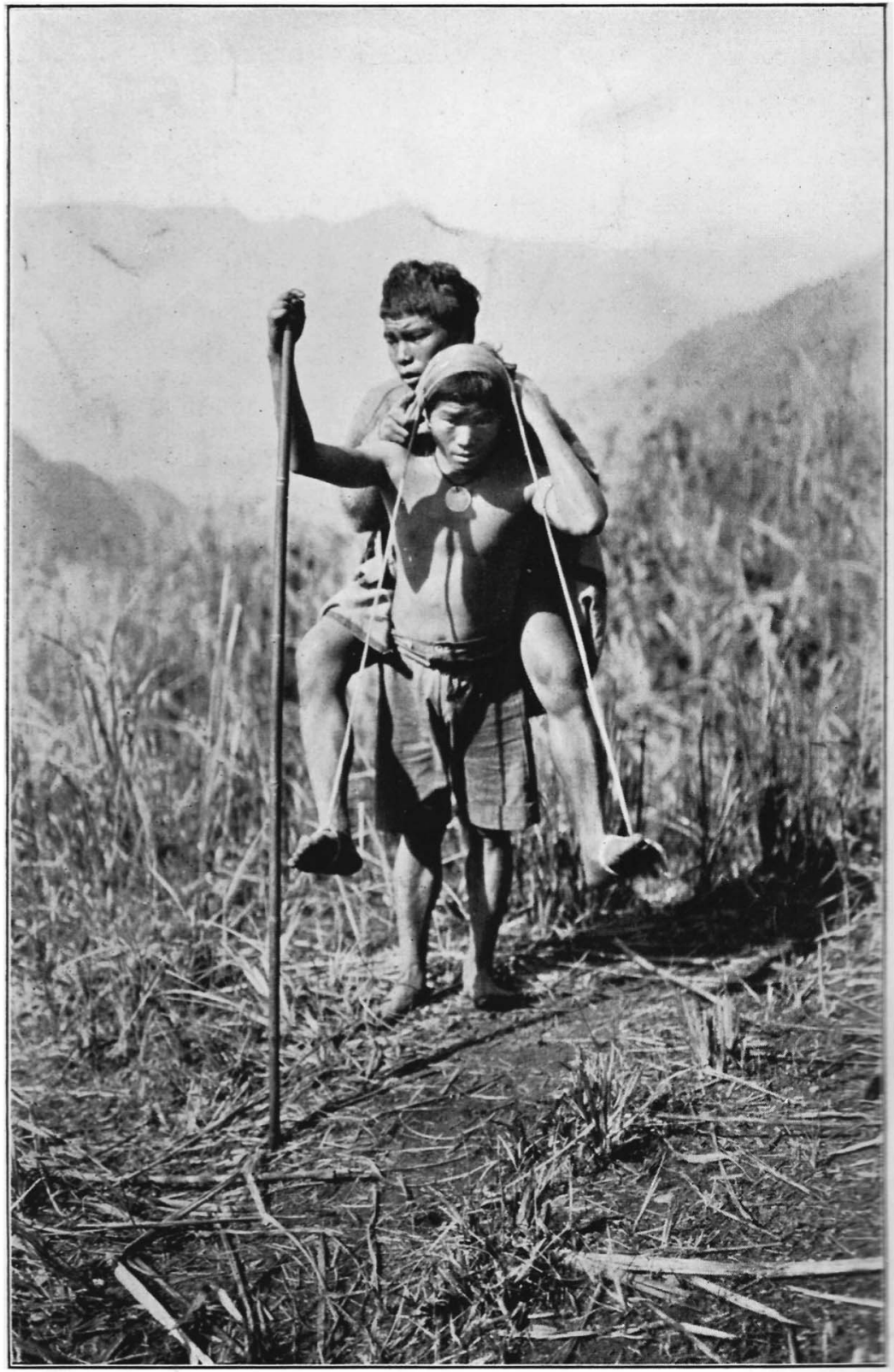

WOUNDED NAGA COOLIE.

Figure 3. Coolie work could also include carrying other people, a load still heavier than the standard sixty pounds.

Photograph: Angus Hamilton, from In Abor Jungles, p. 243. 
the Khabvumas, the contractor employed the "Mao coolies", who were reported to be "cheaper". ${ }^{82}$

While some Nagas began to engage slowly in the emerging wage labour economy, others at the same time resisted the demands of the colonial state in various ways. For instance, flight was a potent means of defence and protest in the Nagas' strategy of resistance to tax, corvée, and forcible impressment for military expeditions. ${ }^{83}$ Another tactic was migration, with many individuals and families leaving their homes in order to escape taxation and forced labour. In January I92I, while passing through Ayenbung village, Hutton interviewed "one Goanbura of a village of Betes [who] admitted that he had settled in Diger to avoid being impressed with other inhabitants of the North Cachar Hills for a Lushai Expedition" ${ }^{84}$ Another "Thado admitted that he and his fellow villagers had migrated from the Naga Hills to the North Cachar Hills but had come back because it was possible to sit in Diger without being called on to work on bridle path or to carry load or to supply rice." ${ }^{85}$ Further, "an old Kuki gaonburra [...] admitted having moved to Diger to escape work on the Henima Bridle path" ${ }^{86}$ Hutton goes on to add, "The story is everywhere the same, and is frankly admitted by these immigrants." ${ }^{87} \mathrm{By}$ resorting to such acts some of the hill populace refused to give in to the demands imposed by the colonial state. And yet, there was also a group in the Naga Hills which came to have an important stake in the colonial order of things, to which we now turn.

\section{COLONIAL CHIEFS}

It was in 1882 , in the aftermath of the pacification campaign in the Angami country, that Charles A. Elliott, the Chief Commissioner of Assam, established a two-layered agency in the Naga Hills, i.e. the headman or lambardar and the interpreter or dobhashi. Elliott described the measure as one which would inaugurate a change, "from the democratic and independent habits $[\ldots]$ into one of subordination to a council of

82. "Tour Diary of E.T.D. Lambert, D.C. Naga Hills for the Month of June I938”, GRC.

83. Michael Adas, State, Market and Peasant in Colonial South and Southeast Asia (London, 1998), p. 233. For instance, coolies employed by Albert E. Woods in 1900 "bolted leaving the load" at Lemhama. In another instance, in 1923, while touring the Konyak country, John H. Hutton wrote that "eight of his coolies ran away" after passing through Longphong. See F\&PD, External - A, May 1900, nos I 52-I 53; J.H. Hutton, "Diaries of Two Tours in the Unadministered Area East of the Naga Hills", Memoirs of the Asiatic Society of Bengal (1929), p. 4I.

84. "Tour Diary of J.H. Hutton, D.C. Naga Hills during the Month of January I92 I", GRC. These stories were extracted by Hutton during a visit to the Ayenbung village, which was mostly a "mixed village of Thado and Bete Kukis".

85. Ibid.

86. Ibid.

87. Ibid. 
elders under a village headman". ${ }^{88}$ Apart from assessing revenue for the state, the headman was required to allocate or distribute labour demand among the households of a village. For his services, the headman was to receive 20 per cent of the revenue collection. ${ }^{89}$

These headmen proved very useful to the government in labour conscription for road works. During one of his tours in 1917, H.C. Barnes, the Deputy Commissioner, was quite impressed with the headmen of Phozanagwemi and Phozanasami, who reportedly brought ninety coolies for working the village path. ${ }^{90}$ The service of the gaonburbas was also crucial in locating and counting houses and subjects. This was especially so since the government had little or no information on the number of houses in the Naga villages. ${ }^{9 \mathrm{I}}$ The headmen could also be held responsible for delays in supplying labour to the district officials. In one instance, having failed to bring in any coolies for the tour party of John Henry Hutton, the DC of Naga Hills, "the gaonbura ate stick" flogged]. Further, the carrier corps accompanying the punitive columns in the frontier was often organized and placed under the supervision of the headmen.

The supply of labour to the colonial administrators and the threat of retribution further came to shape the relationship between the different village khels. ${ }^{93}$ Communities were often divided into factions, with rivals refusing to go out on labour levies. Thus at Mozungjiami village a conflict arose between the various khels on the question of supplying labour. "The upper khels mildly suggested that I should burn the lower khel, and then they themselves would supply my coolies", recorded Albert E. Woods in his tour diary. ${ }^{94}$ On another occasion, while requisitioning coolies for a proposed visit to Furkating, Hutton observed some trouble between the village of Imbarasa and Lisio over the allocation and "proper shares" of coolie labour.95 This then shaped new distinctions and conflicts between the khels and communities in the Naga villages.

In the facilitation and consolidation of colonial rule the dobhashis or interpreters constituted another important institution. They operated as

88. F\&PD - A, January i 882, nos I34-I37. Following Elliott's proposal, Major Michell, the Political Officer in the Naga Hills, appointed twenty headmen in the Naga Hills.

89. Ibid.

90. "Tour Diary of H.C. Barnes, D.C., Naga Hills, I916”, GRC.

91. See Peter Robb, "The Colonial State and Constructions of Indian Identity: An Example on the Northeast Frontier in the I88os", Modern Asian Studies, 3I (1997), pp. 245-283, 26I; see also "Tour Diary of K. Cantlie, officiating D.C., Naga Hills, I919", GRC.

92. "Tour Diary of J.H. Hutton, D.C., Naga Hills, I92 I", GRC.

93. A khel comprised several clans and each khel inhabited a designated area within the village.

94. "Tour Diary of A.E. Woods, D.C., Naga Hills, 1900", GRC.

95. "Tour Diary of J.H. Hutton, D.C., Naga Hills, 192 I", GRC. 
interpreters in road works and escorts during military campaigns. ${ }^{96}$ The dobhashis were also assigned the task of communicating to the villages the government labour demand for road works. For instance, during the construction of a new road between Cheswejuma and Yarabama, Captain Albert E. Woods sent his "Dobhashas to call in thirty Chajubama coolies and thirty Yarabam coolies to work tomorrow cutting the road. I hope", Woods wrote, "to get about 200 men working daily". ${ }^{97}$ In addition to these tasks, they also furnished district officials with news and intelligence..$^{9}$ However, owing to their position in the colonial system, the dobhashis could also misuse their power and oppress people by extorting money from the coolies as well as the villages. ${ }^{99}$ At other times, they could also enhance their social standing. For instance, Charles Ridley Pawsey, the DC of Naga Hills, writes about Imlong, the Chang dobhashi, who had set up a shop in Mokokchung from which he issued rations to the carriers on the march. He also accompanied Pawsey as guide in punitive expeditions and was the head interpreter in camp. ${ }^{100}$ By I930, the number of dobhashis in the Mokokchung subdivision stood as follows: ten Aos, four Lothas, four Semas, three Changs, and one Konyak. ${ }^{\text {Ior }}$ Increasingly emerging as dominant brokers between society and the state, dobhashis continued to hold a considerable stake in the colonial administration in the Naga Hills.

\section{CONCLUSION}

In the nineteenth century and the first half of the twentieth century an expanding frontier meant that colonial officials relied heavily on coercion to recruit "coolie" labour for "public works" and to provide various

96. F\&PD - A, May I873, nos 271-274; “Tour Diary of Captain A.E. Woods, Officiating D.C. of the Naga Hills for the Month of May i 893", GRC.

97. "Tour Diary of Captain A.E. Woods, Officiating D.C. of the Naga Hills for the Month of March i893", Sl. No. 434 (S), KSA.

98. "The first thing in the morning", wrote Lt C.R. Macgregor, Detachment Commander, 44th Regiment, Sylhet Light Infantry at Kohima, "a Dobhashi of Kohima came in [...] and reported that the road was panjied and obstructed, and resistance intended"; F\&PD - A, January I880, nos $498-5$ II.

99. In I893, Albert E. Woods, the DC of Naga Hills, received complaints against five Ao dobhashis, who were accused of "having extorted money from the coolies, and also from some villages". See "Tour Diary of Captain A.E. Woods, Officiating D.C. of the Naga Hills for the Month of March I893", Sl. No. 434 (S), KSA.

I00. Pawsey further writes that Imlong "has far more influence than Sittobung who always was thick headed but who now owing to age and drink is worse than ever"; "Tour Diary of C.R. Pawsey, D.C., Naga Hills, I938", GRC.

гог. Piketo Sema has argued that with the gradual incorporation of the Naga "tribes" into the fold of administration, the appointment of new dobhashis for representing tribes having different linguistic groups and regions became increasingly necessary; see Sema, British Policy and Administration in Nagaland, pp. 34, 35. 
support services in the region. Roads which were laid out in the hills soon came to replace what Penny Edwards has referred to as the "tyranny of distance" with a new "tyranny of proximity", which extended the reach of the state in a myriad ways, from colonial armies dispatched along routes to crush dissent to mobilizing corvée labour to lay new roads. ${ }^{102}$ Furthermore, to borrow Edwards's words, the "liberating road" taking the hill people to markets also took tax collectors to the hill people, besides taking people away from their homes to serve as porters and carriers in the various frontier wars. ${ }^{103}$

This article has focused on the intimate connection between the need to ensure adequate supplies of labour and the push to pacify and conquer. "Coolie" labour on the frontier was "political labour". Coolie work was, however, much resented, and the Nagas often countered this by developing tactics to avoid work and minimize their labour. ${ }^{\mathrm{IO4}}$ While some Naga villagers deserted their households to evade a much-resented colonial imposition, others, such as the headmen and dobhashis, came to play a crucial role in collecting the resources demanded by the state. These intermediaries then became a striking feature of authority in the hill society. In the course of time, some of these individuals also emerged as "men of status" within their communities. In 1924, Surendra Nath Majumdar, the Medical Officer at Mokokchung, gave a description of one such person. Imna Meren, an Ao chief and chief interpreter at Mokokchung, had built "a large house roofed with corrugated sheets", and was the owner of "I 50 'mithans', the price of each being on average rupees

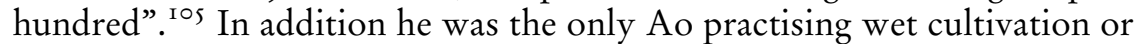
"panikhets", an indication that he also owned the better cultivable lands in the area. ${ }^{\mathrm{I} 06}$ This example shows how, through their position in the colonial system, individuals like Imna Meren could enhance their social standing in the Naga Hills.

I02. Penny Edwards, "The Tyranny of Proximity: Power and Mobility in Colonial Cambodia, 1863-1954", Journal of Southeast Asian Studies, 37 (2006), pp. 42 I-443, 427.

I03. Ibid. For an important work on the impact of labour recruitment on peasant societies in Africa, see David Killingray, "Labour Exploitation for Military Campaigns in British Colonial Africa I 870-1945", Journal of Contemporary History, 24 (1989), pp. 483-50I.

I04. Douglas Haynes and Gyan Prakash, "Introduction: The Entanglement of Power and Resistance", in idem (eds), Contesting Power: Resistance and Everyday Social Relations in South Asia (Delhi, 1991), p. 2.

I05. Surendra Nath Majumdar, "The Ao Nagas", Man in India, 4I (1924), p. 43. Imna Meren was the head dobhashi in Mokokchung from I June I914 to 21 October 1917. See Purtongzuk Longchar, Historical Development of the Ao Nagas in Nagaland (Dimapur, 2002), p. 374. The "mithan" (Bos frontalis), a semi-wild bison, is a highly valued animal among the hill "tribes" and is a symbol of wealth and status.

106. Ibid. "Panikhets" is a form of farming where terraces are built on steep hillsides for wet rice cultivation. 
Labour conscripted from the Naga Hills continued to be extensively used in colonial pacification campaigns in the North-East Frontier. Moving across colonial boundaries, these coolies were employed largely for transport in frontier expeditions and to build colonial infrastructures such as roads and military outposts. What is more, the use of coolies to carry supplies was to be only the first step in the conscription of Nagas by the colonial authorities - later, they would also be used to serve the British Raj in global wars. This was particularly evident during World War I, when more than 2,000 Nagas served as part of the Indian labour corps in the trenches of north-eastern France. ${ }^{107}$ In addition, a large number of Nagas would again be conscripted for building roads, carrying loads, and as guides, interpreters, and soldiers, etc., for the allied troops during World War II, especially in the India-Burma-China theatre of war. The history of these war services - to be explored in further detail in future studies - can only be understood, however, as a continuation of the practice of forced labour extraction which reaches back into the i 880 s. 